\title{
Social inclusion and local practices of belonging
}

\author{
Rob Garbutt
}

\begin{abstract}
Social inclusion is often conceptualised through a spatial metaphor which places boundaries on society, yielding the included and excluded. This paper argues for a relational understanding of society, in which all are implicated to varying degrees in practices and structures that privilege and disadvantage individuals and groups. The implication is that social inclusion policy requires an approach that develops programs that reduce exclusion while also addressing practices and norms that socially exclude.

The focus of the paper is one aspect of social inclusion: achieving a sense of belonging, particularly at the everyday, local level. Belonging in this everyday sense can be thought of as an ongoing project achieved through everyday practices, rather than solely in terms of membership of a group. While many such practices, for example regularly engaging in team sports, are accepted ways of establishing and maintaining belonging, for others in a community practices of belonging may necessitate disrupting or at least broadening the established norms of how one belongs.

To ground this discussion of inclusion and belonging, this paper draws on practices of belonging in a regional community. Established norms of belonging are examined through the idea of 'being a local', a way of belonging that appears to be based on membership. The paper then turns to two local projects which disrupt the exclusive bounds of local membership and attempt to establish new and inclusive practices of belonging. To conclude, parallels are drawn between the boundaries which define 'the social' in social inclusion and 'the local community' in being a local, to argue for the importance of including relational understandings of social inclusion in policy debates and program formulation.
\end{abstract}

\section{Introduction}

This paper explores those aspects of social inclusion that are a product of relationships at the local level. In particular, my interest is in those aspects of inclusion that relate to people's senses of belonging within a local community. Explorations of this type often conceptualise senses of belonging in terms of membership, that is, being included in a group or excluded from it. Conceptualising belonging as membership, however, leaves the field of belonging reasonably static; it ignores the agency of individuals and groups to contest the boundaries of belonging at the local level, as well as the agency of those who are active in boundary maintenance. It also ignores how individuals' senses of belonging vary over time. Therefore, following the groundbreaking work of Elspeth Probyn, in this paper belonging is not solely conceived as membership, but as a sense of connection to others that is always in the process of being actively achieved (Probyn 1996). This approach focuses our attention on practices. 
Here I particularly want to explore how practices of inclusion and belonging at the local level have the capability of expanding local understandings of who belongs in a place. Such practices, which challenge established and apparently coherent senses of belonging are never straightforward in their effects, because in any change in the dynamics of relationships between people in a place there will be resistance to that change. Nevertheless, that resistance is the product of new possibilities appearing that begin to question the very coherence, if ever it existed, of established patterns of local belonging.

In staking out the scope of this paper, I have already drawn on words and ideas which are the subject of intense debate in themselves: community, social inclusion, and belonging are just three. Before entering further into the field of practices of local belonging and social inclusion, it is worth spending a few moments to explain how I intend to use these interconnected terms. Prior to that discussion, however, I should make explicit my overall approach to this research area.

I situate myself in this discussion as a cultural studies practitioner, and following Nick Couldry's lead, my interest is in the 'complex and contested nature of [everyday] culture' (2000, p.2). This concentrates one's attention on 'think[ing] of culture in relation to issues of power: the power relations [...] which affect who is represented and how, who speaks and who is silent, what counts as “culture” and what does not' (2000, p.2). Two outcomes of this set of concerns are a multidisciplinary approach to studying the complexity of culture, often using a mix of methods; and an ongoing engagement with 'others' who are marginalised and dispossessed (Zylinska 2005, pp.35-39). Within this framework, my approach has not been to research marginalisation from the 'edges' of culture, but from the hegemonic centre; the practices of the included rather than the excluded, and especially the language with which inclusion and exclusion are framed. In relation to local belonging and inclusion, this interest stems from questioning my own self-description as 'a local' of the town in which I was born and bred, Lismore in northern New South Wales, Australia and which also happens to be the place in which I now conduct my research. In considering this conjunction of belonging, social inclusion and being a local I have drawn on a variety of research from cultural studies, cultural geography, sociology, critical race theory, anthropology and linguistics. For method, I rely primarily on Norman Fairclough's critical language study method for the analysis of print media (and occasionally, television) texts (2001). The ideas of who is and isn't 'a local' form the centre of this analysis. 
The community which is the primary focus of this paper is that of a rural Australian town, though a metropolitan community also plays a complementary role. This usage of 'community' with its connotation of a group of people with a shared local culture belies the complexity of the term. With the idea of community, and of place-based community in particular, there is inherent tension between a sense of coherence of 'the community', the diversity of the communities in a place, and the ways in which those communities are constituted. As Leonie Sandercock writes, a locality may be 'criss-crossed by networks of social relations whose scope and extent range from neighbouring houses and a few weeks' acquaintance to religious and kin relations spanning generations and continents' (2003, p.93). These criss-crossing networks are made ever more extensible and fluid by new communications technologies from email to Twitter.

While Sandercock's community of criss-crossing networks portrays a community that appears constituted more by holes than by wholes, people thrown together in places can combine in ways to produce the social infrastructure which may dampen the effects of disadvantage or social exclusion (Richardson \& Mumford 2002, Vinson, 2007, chapter 6). Conversely, aspects of social infrastructure such as commonly agreed norms of dominant groups can generate a high level of cohesion amongst those groups, along with domination of resources, to the exclusion of others. The development of communities that are inclusive and resilient requires a balance of openness to others and a sense of connection to that place. In this paper I am particularly interested in this tension between openness and closure, whether that closure is concerns those closed in (the included) or those closed out (the excluded).

With this focus on the local scale in terms of 'community', it is important to emphasise the multi-scalar nature of social inclusion; to recognise that the processes that produce social inclusion operate simultaneously at the small and larger scales. The focus on local practices of belonging and inclusion that this paper takes bears larger scales in mind for good reason: as Angus Cameron cogently argues, in discussions of inclusion and exclusion the 'occlusion of the non-local [...] has profoundly distorting effects. It makes it very much easier to see exclusion as a feature of people in places rather than the wider histories and geographies of a complex polity, culture and economy' (2006, p. 398). Issues of exclusion in a community must be examined across a range of scales that extend beyond the community. For example, the case studies of practices which seek to expand ways of local belonging that are examined 
towards the end of this paper do not arise solely from a local context, but are community members' responses to a perceived social atmosphere of fear and exclusion of 'others' that, since the late 1990s has been simultaneously local, national and global.

In this paper, the term 'social inclusion' is understood within this multi-scalar framework. Social inclusion is understood to be a product of social institutions, processes and practices, which inevitably produce unequal outcomes for individuals. These outcomes depend on how one is positioned at the intersection of different power grids in society (Yuval-Davis, Kannabiran, \& Vieten 2006, p.7). It is, therefore, a multidimensional, relational concept that describes the nature of individual and group relations to the larger society (Silver 2007, p. 15). In general terms one can understand social inclusion to be a state of privilege that has as its corollary, a state of disadvantage or social exclusion. Further, as the centre, or the socially included is typically a group that is unmarked, it is more common to find working definitions of social inclusion that refer to the marginalised or marginalisation, that is, 'as "not social exclusion"' (Cameron 2006, p.396). With this in mind, this paper attempts to identify the centre of social inclusion, as well margins. In terms of belonging at the local level, this involves identifying 'the locals' as well as those considered not be locals (Garbutt 2005).

In line with this understanding of social inclusion, the aspects of social inclusion that this paper concerns itself with are those which Hurriyet Babacan terms the 'relational aspects' of social inclusion, rather than 'distributional aspects'. Relational aspects of social inclusion include 'culture, ethnicity, racism and other diversity signifiers as a causal factor of disadvantage' (Babacan 2008). As Babacan notes, these are the aspects of social inclusion that are not generally addressed in the current Australian Federal government's agenda for social inclusion, an agenda which gives priority to labour market initiatives, specific localities, homelessness, people with disability and Indigenous Australians (Australian Government n.d.). While the government's focus on specific measures and groups is understandable, particularly as a way to target funding, this paper argues that it is important to include relational aspects of inclusion that incorporate whole of society strategies.

There are two key points to my argument for including Babacan's 'relational' aspects into social inclusion initiatives. The first, as she notes, is that relational aspects are often causal factors of social inclusion. To ignore causal factors as part of the social milieu from which exclusion arises, risks the long-term sustainability of more targeted measures. Underpinning 
this is the second aspect of my argument, and that is that without incorporating a relational understanding of social inclusion into policy frameworks, the concept of social inclusion becomes one which casts the excluded as the problem to be solved, and those who are included having no significant part to play in developing a more inclusive society apart from 'lending a hand'. This is a consequence of both defining inclusion in negative terms, as noted above, and using a model of social inclusion that is based on conceptualising society as a 'bounded space’ with an inside and an outside (Koler \& Davidson 2008). This model has some usefulness in identifying those groups that need to be brought 'in towards the centre', however, if the centre does not shift in its relations with marginalised people, there is no reason to expect that those who have been systematically excluded will not be so again when short to medium term targeted programs finish (Labonte 2004). Rather than conceptualise society as a bounded space, this paper conceptualises a relational space in which all are members of a society and none are 'outside'. By taking this view, the focus is on the social practices and relations which marginalise some groups and individuals. In the terminology of the bounded space metaphor of society, this involves the 'centre' as well as the 'periphery' in new, more inclusive forms of social relations.

Issues of belonging and practices that include and exclude, then, constitute the third area that this paper deals with, and that deserves preliminary discussion. Belonging, as it is understood in this project, concerns 'experiences of being part of the social fabric' (Anthias 2006, p. 21). These experiences include membership of collectives (for example, voluntarily becoming a citizen of an adopted country or involuntarily being a member of a group through birth). Importantly, however, belonging also arises from everyday practices and events (Probyn 1996, Sicakkan \& Lithman 2005). These practices could include a daily routine of surfing, regular employment, or cooking and sharing a meal with others. In these examples, belonging is experienced in neighbourhoods and communities, through which larger-scale (national and transnational) experiences of belonging are mediated. The achievement of belonging, however, may be constrained through membership of a group which is socially excluded due to the actions of others including governments and the media. What harms communities in such instances is 'the preemptive exclusion [...] of others on the basis of the codification of others as outside relation, belonging nowhere, a threat' (Diprose 2008, p.47). Belonging may also be constrained by a range of other considerations such a lack of transport, or poverty, or narrow constructions and representations of national identity. Thus, belonging is directly connected to the distributional and relational aspects of social inclusion. A sense of 
belonging develops and is continually sought through finding and making one's place and through one's positioning according to social structures and practices (Sickakkan and Lithman 2005 pp.20-27, Bhambra 2006, p. 37).

In this paper, I am interested in practices that are intended to challenge the extent of local belonging. These are practices of belonging that can bring some members of a local community into tension and conflict with dominant groups, either when established practices are brought into question, or when existing definitions of local membership (which are often unspoken but nevertheless real) are opened for the admission of new identities and ways of belonging. These types of practices of belonging do not leave the centre undisturbed by the periphery. Rather, they are aimed at establishing new sets of local relations and opening and extending the experience of belonging of those who may somewhat rigidly adhere to established social patterns. By challenging dominant structures and practices they aim at developing and extending social inclusion at the local level.

The following sections of this paper explore local belonging in Australia and its relationship to social inclusion by focusing on belonging as membership and as an ongoing project in the region around Lismore on the New South Wales far-north coast. The discussion of belonging as membership focuses on the idea of 'being a local', or to more accurately represent the collective nature of relationships in a place, 'being one of the locals'. Questions of explicit and implicit rules of membership are explored by analysing the usage of the term 'local' in the local print media. National dimensions of this form of belonging are examined through an analysis of metropolitan newspaper coverage of the locals before and after the Cronulla 'riot' of December 2005. This examination of belonging as membership will be followed by discussion of two examples of projects which encourage practices of belonging by individuals who might ordinarily fall 'outside' the bounded space of membership as a local. These practices not only create new sets of supportive relationships within a place but also challenge the 'centre', in this case, the locals, to be open to new ways of being local. This process of opening is not always harmonious as it often contests normalised connections between people and place. The final section of this paper ties these discussions of belonging back to government programs aimed at developing a socially inclusive Australia. 


\section{Being a local: membership and exclusionary practices of inclusion}

Local belonging in many places throughout Australia, both in cities and the regions, is often organised by a specific social form in which some individuals closely connect place to their identity through the idea of being a local (Myers 2006, p.325, Garbutt 2006). I use the term 'organised' here to convey the sense that other ways of belonging in a place are often measured against this idea. It functions as a benchmark for interrogating place-based authenticity: Are you a local? The question is one which gauges a range of considerations from whether someone can be relied on to give directions, to whether a person has the right to speak for a place in a public forum, to who is privileged in setting the local rules for behaviour. Such considerations are not isolated from larger scale processes, with rules of gauging belonging at the local scale often being the product of practices that are simultaneously local and national (Marston 2000).

One means of analysing the idea and practices of being a local is through the print media. The two case studies that follow, one centred on the region around Lismore in northern New South Wales, and the other on the Sydney beach-side suburb of Cronulla, draw on a critical language study of media texts. In the case of the Lismore region, between January 2004 and May 2005 each issue of the regional daily newspaper The Northern Star was surveyed for the use of the word 'local' and 'locals' and the instances catalogued. This was a manual process of reading and transcribing 607 instances of use as the newspaper did not have an Internet presence or searchable database available at that time (Garbutt 2007). In the discussion below, some more recent examples from The Northern Star and the weekly Northern Rivers Echo have also been used to supplement the data for illustrative purposes. For the Cronulla case study, the Factiva database was used to find all 512 occurrences of the word 'locals' in two daily Sydney newspapers, the tabloid The Daily Telegraph and broadsheet The Sydney Morning Herald, for the three-month period centred on the 2005 Cronulla 'riot'. As 'locals' may only be used as a noun, whereas 'local' may be used as a noun or adjective, the word 'locals' was chosen as the only search-term in order to quickly gather data on the noun-use of the word.

The critical language study utilised the method that Norman Fairclough outlines in Language and Power (2001). As the term implies, a critical language study aims to show up connections between language and power that may not be apparent on the surface. Critical 
language studies take a discourse view of language: a view that language is a form of social practice that is conditioned by social conventions (2001, p.18). Social structures, then, give rise to certain structures in language, and conversely language plays a part in the (re)production of those social structures. Language, therefore, portrays certain social structures and practices as common sense, natural or normal and so is a fundamental tool for the maintenance of power structures and power relations between social actors (Smith 2006, p.82). Being a local is part of the 'linguistic repertoire' of place-based power relations 'that are ultimately a matter of who may or may not do what, when and where' (Pred 1990, p.33).

Because discursive processes represent and reproduce social structures, they are not only processes of social maintenance but also sites of social change. Of relevance here is Stuart Hall's concept of articulation. For Hall articulation has the double sense of 'giving expression to' and a connection between one thing and another (Hall 1996, p.141). These connections may appear to be natural-between farmers' interests and legitimate local interests, for example, or between a lack of legitimacy to speak for a place and being a 'blow-in'-but on analysis these natural connections are often revealed to be historical, social constructions which are contingent and open to rearrangement. A critical language study opens language to an analysis of these relations and the embedded ethos-'what the customary attitudes, values, and practices of a group are' - to a wider ethical consideration of how those relations could and 'should be' (Ball 2005, p.31). My particular focus in the analysis below is on the articulation of power, belonging and race.

In the local print media based in Lismore, covering a region of around 100,000 people, the locals are continually asserting a privileged connection to place in their encounters with others. At nearby Byron Bay, a favourite stop on the global backpacker route, the locals, tourists and tourism interests constantly jostle over 'ownership' of public space. On a more widespread basis, since the 1950s the sub-tropical rurality of this region has drawn a steady sea- and tree-change migration that has accelerated from the 1970s onwards (Kijas 2002, p.116). For the countryminded Lismore of the 1970s it was the Aquarius Festival, an alternative student happening held over ten days at the nearby village of Nimbin in 1973 and which never really ended, that through contrasting lifestyles gave the locals greater cultural visibility. Thirty years later the 'hippy' or 'new settler'/local divide has blurred considerably, with that language itself becoming quaint or obsolete, only to be once again resurrected in situations of cross-cultural tension. In these and a range of other contexts, questions of who 
properly belongs here, who may assert cultural possession of public space, and who may or may not speak for a place are often settled in terms of who is or is not a local.

One way of defining belonging as a local is explicitly articulated. If there is a question of one's status as a local, conversation typically and quickly moves to duration of residence as the following examples demonstrate:

When I first came to Lismore twenty-five years ago, people told me it takes 25 years to become a local ... My time’s up. I think I can safely say I’ve made it, ( Nora VidlerBlanksby quoted in Satherley 2004, p.3) or

All [the people I have just mentioned were] born and bred in the area, plus John Chant, who has been here for 40 years, which makes him a local, (Baxter 2004, p.11) or

While many of the anti-[Repco car]rally people look like they come from greater Nimbin they are, in fact, long-time residents of Kyogle shire. As one woman put it, her child was a "third generation hippy" from a family that had been in the council area for 40 years. Mind you, 40 years is but a blink compared with the time many grazing families have been in the area, (Brown 2009, p.11) or finally

Candidates [for Lismore Council elections] were given between two and three minutes open mic time and stayed mostly on message, apart from competing for "most local”, won by Greens candidate Laurie Axtens, who is a fifth-generation Lismoron (Maxwell 2008).

Becoming local takes time: routine, everyday time spent on the ground. There is a notion here of connection between identity and a 'patch of dirt', of authenticity through autochthony, of being a child of the soil, of coming from a womb and from a place, of being born and bred. Being local weaves identity and place together in this most intimate fashion. A local's sense of identity emerges through time from a developing everyday personal relationship to place through a meld of history, community and geography (Miller 2003, p.217). To come from outside Lismore, and move beyond being 'just a blow-in'-an unannounced stranger blown off-course - the honorific must be earned through an infusion of soil into one's blood. The period required for this metamorphosis is clearly open to question: twenty five years, forty years, five generations. In a sense, locals were never not here. History begins with their arrival, and somewhat paradoxically, with the forgetting of that arrival. 
The settled place of the locals, articulated through history, community and geography of necessity excludes. In de Certeau's words locals define themselves within a 'proper place' 'a place appropriated as one's own' - 'in a world bewitched by the invisible powers of the Other' (1984, p.36). An analysis of the use of the word 'local' reveals how the idea of being 'a local' stabilises local belonging through concealment of self and other. A local, understood as 'an inhabitant of a particular locality' is a substantive, or noun-equivalent, of the adjective 'local' (Oxford English Dictionary 1989, p.1079). The noun which the adjective 'local' modifies is, therefore, understood, elided, concealed. This opens the question, what is the concealed noun? As is often the case, it is somewhat simpler to determine what the concealed noun is not.

The critical language study of seventeen months' issues of The Northern Star shows that within everyday settler discourse Aborigines cannot be noun-locals (Garbutt 2007). To do so, it seems, would pollute the proper place of 'the local' with the Other. Instead, Aborigines are adjective-locals. In The Northern Star Digby Moran is described as a 'local [...] indigenous artist' (Redmond 2003, p.5). Bill Walker, the co-ordinator of the Bundjalung Nation Aboriginal Cultural Heritage Committee, is a 'respected local identity' according to the Northern Star (2004, p.3). These instances are illustrative of the repeated use of the term local as a regular adjective in reference to Aborigines. Local is a modifier of the nouns 'artist' and 'identity', indeed a modifier that refers to an imagined boundary rather than to the land itself. If there was a class of substantives (or noun equivalents) to which 'local' belonged, we would be justified in labelling them dispossessives.

The noun-local excludes more than Indigenous Australians from this settled form of belonging. As the quotes from The Northern Star and The Northern Rivers Echo indicate, there is an underlying normative aspect of belonging as a born and bred local which is especially evident in relation to 'hippies'. Jeannette Edwards explains that this normative aspect of belonging is a key part of the British born-and-bred kinship system that is now widespread throughout the West. This system functions in terms of being 'born' in the 'immutable place of birth' and 'bred' which indicates 'the effects of a variable upbringing' (2000, p.84). Thus, it is a kinship system that is both normative and symbolic: 'it is made up of a code of conduct (what people do and say they do) and ideas of shared substance (symbolized in idioms of blood and increasingly genes)' (Edwards 2000, p.28). This 
juxtaposition of normative and symbolic elements to kinship means that local belonging is complex. Thus:

To be born, say, in a particular place does not axiomatically confer the status of belonging to that place, one also needs to be brought up in a particular way. In the same way as being biologically related to a person does not axiomatically make them kin. A claim of belonging (to persons and places) can be made through upbringing as much as birth. The juxtaposition of being born and bred allows kinship to be conceptualized through both or through either. A variety of ways, then, based on birth and/or breeding are mobilized in a constant process of including and excluding persons from social categories which are, in turn, reproduced in the process (Edwards 2000, p.28).

The function of time spent in Lismore stands in for biology or blood and breeding. In terms of breeding, the longer the time spent in a place, the more likely one is infused with local ways of doing things. In terms of blood, the 'truer' claims to being a local extend across generations. These local bloodlines are white, settler bloodlines. However, born-and-bred kinship complicates this system of belonging. Claims of local status by a flamboyant mayoral candidate who has ‘done her time’, or a car-rally-protesting hippy or Greens candidate making their case through generational links to the local area, simplify and misread the system. Through the less tangible aspect of the code of conduct, conservative locals can dismiss such claims. Indeed it is more likely that a businessman and supporter of the conservative and country-minded National Party, such as John Chant who arrived in Lismore 40 years ago, would have a stronger claim to local status than is afforded by the 40 years of a third-generation hippy. Moreover, asserting one's own local status ignores the protocols of becoming a local: the patronage and acceptance of the established locals is the test. Thus through born and bred kinship, 'hippies' can be excluded from status as locals by the conservative mainstream establishment despite satisfying the only publicly declared rule of local membership: time spent living in a place.

When national and local identity are explicitly contested in the same moment, belonging again takes on issues of blood and a normative code of behaviour. In the instance of the racially-based 'riot' at Cronulla in December 2005, for example, being a born and bred local was expressed not only through the colonial lineage symbolised by the Union Jack in the corner of Australian flags worn as battle colours. It was also expressed through normative 
codes of dress and behaviour that specifically excluded Muslim men and women from 'proper' ways of belonging at the beach. The exclusion was at once local and national, that is, it was more than an issue of local beach etiquette, it was an assertion of national possession as well (Evers 2006, Moreton-Robinson \& Nicholl 2007).

Suvendrini Perera has described the Cronulla riot as 'a performance of native-ised territoriality’ by Anglo-Celtic settler Australians (Perera 2006). This description is supported by media reports in which the locals featured prominently. The Channel Nine News, for example, portrayed the intent of the crowd of 5,000 as 'a show of numbers by locals wanting to protect Cronulla ... turning on individuals because of their ethnic background' (TCN9 2005). These disturbing events began amidst a festive though fiercely nationalist atmosphere 'sort of like Australia Day’ (Sarah, quoted in Jackson 2006). The Australian Broadcasting Corporation's week-night current affairs program, The 7:30 Report, similarly reported that “"Da Boys”, the Cronulla locals, turned up early and by 10am a party atmosphere was already underway’ (Australian Broadcasting Commission 2005). Defiant statements of AngloAustralian possession accompanied this celebration of Anglo-Australian culture: a young man with an Australian flag worn as a cape had the words 'We grew here! You flew here! 2230 [the Cronulla postcode]' written across his torso; ‘100\% Aussie Pride’ was inscribed on the beach itself; a banner held aloft demanded that unnamed others 'Respect locals or piss off!' (Singh 2007; Elder 2007, p.305; Murphy 2005, p.5; Ramage 2005, p.6). The invitation to party was clearly not extended to everyone. At stake was the issue of (who decides) who belongs where; an issue debated using terms in which the dominant position of white settler Australian is already embedded in the language of identity and place, and already localised to Cronulla and Australia.

The language of local identity becomes particularly evident when focussing on the appearances of 'locals' (as a group and as a word) in newspapers in the weeks before and after the riot. The histogram in Figure 1 charts the number of occurrences of the plural noun form of 'local' in the two major daily newspapers in Sydney, The Daily Telegraph and The Sydney Morning Herald (SMH), for the three-month period centred on the Cronulla riot, the reporting of which occurred in the week ending 18 December. The locals become ever more present in reports, from an average of 17 appearances per week for the twelve month period around the riot, to between two and three times that number in the weeks prior to and after the riot. 


\section{Locals in print}

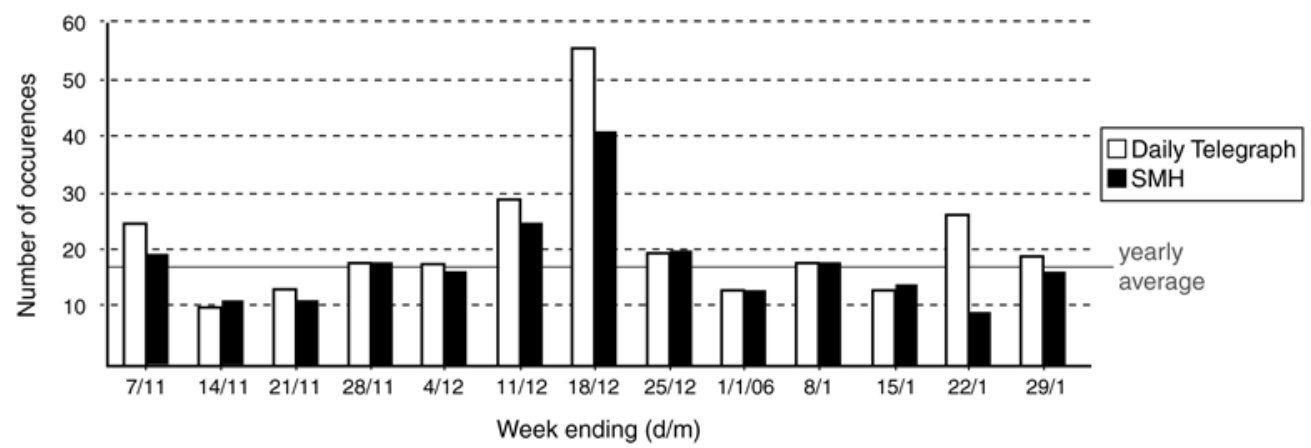

Figure 1 Number occurrences of the noun locals in two major Sydney daily newspapers in the three month period centred on the Cronulla riot of 11 December 2005.

An analysis of data connected with the spike in the week of the riot demonstrates a direct connection between Cronulla and use of the word 'locals'. For example in The Daily Telegraph there were no references to Cronulla locals during November 2005 whereas in December, Cronulla locals featured in 56 percent of uses. By January 2006 Cronulla locals were again fading into the background, accounting for ten percent of appearances.

The locals made their presence felt in the week prior to the riot when a fight occurred between lifesavers and a group of young men of 'Middle-Eastern appearance'. This event proved a turning point that evoked a call to arms. The Daily Telegraph, in tacit agreement, headed a number of letters to the editor on the subject with 'Let's unite to fight this shame on the beaches', including the following:

Sutherland Shire residents have tolerated anti-social and downright un-Australian behaviour from the influx of certain football-short wearing, gang-style riff-raff from the Western Suburbs for far too long. The suggestion now that Cronulla locals may need to travel to out-of-area beaches themselves [...] is absolutely ludicrous (de Vere 2005, p.40).

By the mid-week the sense of dispossession and loss that locals were experiencing transformed itself into action as a text message began proliferating between friends and acquaintances. Through planned action locals were no longer victims of an historic 'influx' but protagonists who would reclaim 'The Shire': 
RACIAL violence exploded again at Cronulla beach yesterday [7 December] as a text message circulated urging locals to take revenge on Middle Eastern gangs. [...] Police have [...] called for calm amid fears the text message's rallying call for locals to "take back The [Sutherland] Shire" this weekend could become a flash point for violence (Daily Telegraph 2005).

Another report explicitly sets out the terms of the dispute, and the limits of the process by which locals' rules were to be negotiated:

\begin{abstract}
In the past, battles have been fought between locals and outsiders on city beaches, but this time it's clearly about race. Locals claim that Middle Eastern gangs overrun Cronulla every weekend, arriving by train and then gathering in groups to harass young girls. [...] The tribal surf culture in Sydney is all about paying respect to the locals. The beach is for everyone, but only if you play by their rules (McIlveen, Lawrence\& Brooker 2005, p. 68).
\end{abstract}

The right of the locals to speak for a place, to define the rules for behaviour and to defend it from others who do not abide by these uncodified rules is a clear demonstration of the way localism marks out boundaries in terms of birth and breeding. That most of these 'Middle Eastern' young people had also been born in Australia is not of consequence. The issue here is that the 'claim of belonging (to persons and places) [... is being] made through upbringing as much as birth’ (Edwards 2000, p. 28). Or as Marilyn Strathern (1996) has noted of maintaining boundaries of belonging to a people and a place, born and bred kinship is as much about cutting networks as much as it is about making them. Local and national intersections define 'not being one of us' which as a consequence leads to social exclusion in the form of denial of social and cultural participation in the wider society (McCrone \& Bechhofer 2008, p.1246).

From the two case examples above, the first from Lismore and the second from Cronulla, we can see how Australian localism faces in two directions to secure the borders of local belonging. Firstly, the language analysis of the usage of 'locals' in the Lismore press defines one boundary which separates conservative, settler locals from Aborigines and another which separates those locals from 'new settlers' or 'hippies'. The Cronulla example more clearly defines the boundary of belonging between settler locals and later immigrants (in this particular case, the later immigrants are people of 'Middle-Eastern' descent). This boundary depends on the forgetting of Aboriginal dispossession, thereby allowing the locals to overturn the prior property rights of Aborigines and to install themselves as having moral priority in a 
place as the first possessors (Garbutt 2006, pp.175-179). The overturning of the natural law of first possession is impure, though not disorderly. It operates around two axes: one which overturns and one which preserves. The first is a racialised axis that overturns the 'natural' order of Aborigine and settler and installs the settler as native. The second axis preserves the order of indigeneity — of being authentically of a place because of being the first from a place. These boundaries defend Anglo-Celtic born and bred localism against the inroads of multiculturalism and Indigenous rights (cf Griffiths, T. 1996, pp.220-224).

The idea of being one of the locals can be seen as an example of belonging as membership. Being a local is predicated on meeting particular rules that vary according to the issue at hand. In one instance these may be unstated rules of racial admission that exclude Aborigines from belonging as locals. In another situation, it may be newcomers in the form of 'hippies' who do not adhere to conservative local norms. In Cronulla it is the newcomers of MiddleEastern descent who are excluded. Of course, the portrayal of local belonging as a form of belonging as membership, as distinct from belonging as an ongoing practice, is simplistic. Local belonging as membership is constructed through social practices which exclude and maintain boundaries. These boundaries concern rules of group membership but also define belonging to a geographic place. The rules of this 'proper place' of the locals, however, are also intimately connected with practices and performances of national identity. These factors, underpinned by the norms of a born-and-bred kinship system, infuse local belonging with the boundaries of nation, blood, and ways of behaving in complex combinations which derive their power, in part, by rarely being explicitly articulated.

In the following section, this paper turns to practices of belonging which include, and in doing so they necessarily disrupt established boundaries of local belonging as membership. They are, therefore, practices of belonging that are also practices of contestation. They seek inclusion, but only by initially creating dissonance.

\section{Becoming a local: practices of belonging which promote inclusion}

While the idea of being one of the locals is maintained through established rules of membership, there are individuals and groups who seek to expand the senses of local belonging through inclusive practices. These practices make a place in the local community for individuals and groups who might not ordinarily be thought of as 'mainstream' locals, thereby unfixing implicit rules of who belongs in a place. In this section, then, belonging is 
predominantly viewed as the product of everyday practices that connect individuals and groups to the social and civic fabric of a place. The two case examples examined here create new spaces for connecting with others in an inclusive, open and public way. By enabling dialogue across boundaries, the boundaries of local membership are themselves brought into question, and through social practices local identity becomes a matter of what one does, rather than who one is. In the process it becomes clear that belonging as membership has always been fluid with the articulation of being a local with such things as race, class, age, gender and sexuality always being arbitrary, even when essentialised and unquestioned. Indeed, the many possible intersections of these and other aspects of identity have meant that the rules for local membership have been under continual negotiation depending on the social situation. Nevertheless, an emphasis on local belonging as membership often means exclusion despite one's efforts to 'fit in', and that is based on criteria that are outside one's control.

Two community-based projects are the focus of this section: Lismore's Living Library and an Anzac Day peace project called ‘Remembering and Healing Old Wounds'. Lismore’s Living Library aims to challenge stereotypes and reduce discrimination against marginalised groups through bringing people together in one-on-one conversations. Remembering and Healing Old Wounds is a 'commitment to eternal vigilance against war' and questioning the role of wars in defining Australian identity (Northern Rivers Echo 2009). Both projects invite members of the community to develop new relationships and alliances. In the case of the living library the one-on-one conversations that take place, and reports about the living library in the media, have expanded the sense of diversity of the Lismore community. The Anzac Day project, meanwhile, provides a place for questioning the use of the Anzac tradition for narrowly nationalistic purposes (McKenna 2007). This in turn creates an inclusive space for those members of the community whose heritage is not from an Australian allied nation, or who feel alienated by the purposes to which Anzac Day has recently been put. Both projects, and their inclusive and sometimes contentious nature, will now be explored in more detail.

The living library concept is a grass-roots response to discrimination and stereotyping. The first living library was organised for the 2000 Roskilde Festival in Denmark by the Stop Volden (in English 'Stop The Violence') non-government organisation (Council of Europe n.d.). The project aimed to bring individual young people together in a short conversation that 
would put a story to difference. In the words of the organisers, participants are encouraged to '[m]eet your own prejudice! Instead of talking about it, simply meet it' (Abergel et al. 2005, p.9).

In living library projects the living books are usually members of groups who are subject to discrimination and stereotypes. A living library session involves a library of living books making themselves available for borrowing by members of the public for a thirty-minute or so 'reading'. Living libraries can take a number of forms. Generalist living libraries are comprised of living books representing a range of backgrounds who might give themselves 'book titles' according to intersections of, for example, ethnicity, religion, sexuality or ability. Alternatively, living libraries can be organised for celebratory or commemorative days, for example, for International Day for People With Disability. In all cases the aim is to provide 'ordinary' community members with the opportunity for a conversation with a person they may not ordinarily meet in order to dispel negative stereotypes and prejudice. In conversation, readers soon discover that the 'book title' is but one chapter of the 'living book'.

In Australia the first living library was launched in Lismore in November 2006. It was organised by a community-led committee who were concerned to counter, through a local level project, a culture of fear of others that appeared to be present at the national level. Lismore City Library now operates the living library on a monthly basis (ABC 2007, Garbutt 2008). Books were actively recruited for local and national reasons: some such as a Muslim, an Aboriginal young person, an African refugee, people with disability, and a person with HIV/AIDS were all members of groups who routinely suffer from prejudice throughout Australia; whereas a hippy and a farmer could be stereotyped for a range of local reasons. The living library project has had a number of effects on the way community is imagined in Lismore. Constant media attention, as a result of partnerships between the living library and local print media organisations, has seen a widening representation of who Lismore is. Meanwhile, within the confines of the living library and the individual conversations, the politics of representation takes on new dimensions where listening becomes a key component of the exchange; as is an unmediated marginalised voice to listen to, respond to, and engage with. What is enabled in these conversations is an opportunity to be open to alternative understandings of the world and one's locale, and doing this together across differences. The journey is risky and personal. As Susan Bickford writes, quoting Merleau-Ponty, in such 
conversations ' $[\mathrm{w}]$ hat I come to understand is not simply the other's perspective, but my perspective in light of his [sic], and his in light of mine - "I learn to know both myself and others"' (1996, p.147).

The possibility is that at a personal level a type of non-assimilationist integration can begin in living library conversations; integration which is based on joint effort and that does not leave dominant groups unchanged (Ang 2008, pp.230-231). Anthony Appiah writes that in such instances ' $[y]$ ou enter a conversation, and conversation is about listening as well as talking; it's about being open to being changed yourself, but it's not about expecting consensus or seeking agreement’ (Brookes \& Appiah 2006). In many ways, living library conversations put established local identity at risk 'by enlarging the variety of relationships which constitute [local] selves' (Sylvain 2005). The living library project, then, is not necessarily about seeking harmony, so much as expanding networks of inclusion. Through living library conversations, through positive media reports and through the subsequent conversations that books and readers have with friends outside the living library confines, new ideas of who belongs as part of the community germinate.

While evidence of a direct causal relationship between improved social inclusion and living library operation is not yet available, a range of small-scale evaluations indicate living library projects have a positive effect on readers' openness towards others (see for example Baltruweit. McIntyre \& Garbutt 2007). In the Lismore project it is clear from living books’ evaluation survey responses that they often challenged readers' assumptions. One living book remarked that 'some people come with preconceived ideas and [are] surprised at how “normal” we are’ (McIntyre \& Garbutt 2007, p.3). A reader at the project launch remarked that, 'Speak[ing] to people openly and honestly enriches my life and draws me closer to them as human beings'. Ninety-eight percent of readers at the launch stated that they learnt something by borrowing a book and there is evidence that negative stereotypes were altered. For example, in a candid comment a reader said that ' $[\mathrm{I}]$ learned that not all Aboriginal people get drunk and violent'. Another stated, 'Many of my assumptions were wrong'; and yet another, 'I learnt mostly how different, yet the same, gays are to the heterosexual community’. Such experiences build social inclusion in a personal way. As one reader put it, 'There are many different types of people in Lismore that are very friendly' (McIntyre \& Garbutt 2007). Similar evidence from other living library projects reinforces these initial indications from Lismore (Living Libraries Australia; Living Library Organisation). 
The Anzac Day Remembering and Healing Old Wounds project is of a much different kind to the living library project. The living library challenges dominant views of belonging and place, as well as acting to dispel stereotypes and reduce discrimination, however the project has raised few, if any, public objections. The Remembering and Healing Old Wounds project, on the other hand, is an intervention that concerns Anzac Day commemorations and which, therefore, connects to deeply held, even 'sacred' ideas of Australian national identity. In 2009, the first year of the project, two events were organised: an Anzac Eve service, and the Remembering and Healing Old Wounds ceremony, held on Anzac Day following the official program that is regulated by the Returned Services League (RSL). Around one hundred people attended the Anzac Eve service which included a reconciliation ceremony involving Australian and Japanese representatives. The Anzac Day ceremony involved 'people representing many different faiths and backgrounds, from Christians and Jews to Muslims, Japanese, refugees, young people and many others’' (Sword 2009).

It was the ceremony on Anzac Day that caused the most division amongst community members. As the secretary of the Lismore sub-branch of the RSL wrote in the lead up to Anzac Day:

I cannot understand or fathom why this group insists on holding [the ceremony] on Anzac Day. It's beyond belief that they would choose a day that is sacred to the ex-service community and the citizens of Australia when they could have it on any other day of the year ... Anzac Day is more significant to the general public psyche of what it means to be Australian than any other day and, as such, it should ... not be diminished in any way. I find their self-interest in holding this event when they have been asked not to goes totally against the spirit of Anzac Day, which is about self-sacrifice for the common interest (Sword 2009).

A past national president of the RSL provided the alternative view:

While Anzac Day is about commemorating those who gave their lives in the defence of Australia and the service of those who returned, it is appropriate to remember all those who have died in war, including our enemies, if we are to reinforce the lesson of the futility of war and renew our commitment to peace... In my experience, it is those who have been through the worst of war who are the first to acknowledge its folly (Sword 2009).

These two views on the Remembering and Healing Old Wounds project represent the lines along which divergent views were expressed in daily conversation and letters to the editor. 
With the stated aim of promoting peace and harmony, this division makes the project a complex intervention to analyse, however in terms of opening a space for conversation about an issue that goes to the core of national identity the project is extremely effective. The three women who organised the celebration, one who 'grew up in devastated post-war Germany', another 'a Jewish woman whose grandparents survived the Holocaust', and another who is 'an Australian woman born during WWII' embody the tensions of negotiating national belonging at the local level in a multicultural nation (Northern Rivers Echo 2009). Part of that negotiation, just as with controversies over Australia Day/Invasion Day, is to create public opportunities for dialogue about the dominant narratives that accompany Anzac Day and how these narratives position people in relation to the nation to which they belong. Again, following Appiah’s idea of conversation, this is about listening as well as speaking, and not necessarily about seeking harmony but of getting used to living in a globalising community in which difference is part of life. Recent conversations between the Remembering and Healing Old Wounds project organisers and the local RSL sub-branch demonstrate that this dialogue across difference is continuing and that there are possibilities for a co-ordinated approach to a diverse range of activities for Anzac Day 2010.

\section{Social inclusion and local practices of belonging}

This paper began by arguing for a relational view of society rather than one solely expressed through a spatially bound metaphor. While it is difficult to maintain this sense of society when writing about social inclusion and belonging-language such as centre and periphery, marginalised, inclusion and exclusion all convey this spatially-bounded sense-it is important to hold onto the thought that through relationships all people are products of a society and part of it. For this reason the quality of social relationships, in particular their inclusive quality, is important. Consequently, it has been argued here that relational aspects of social inclusion are important aspects for social inclusion policy as they are 'causal factor[s] of disadvantage' (Babacan 2008).

In order to develop this argument at the local level, this paper has taken local belonging as its focus. Again, belonging at the everyday, local level is conceived of in relational terms and as an ongoing project achieved through everyday practices rather than solely in terms of membership of a group. While practices such as regularly engaging in team sports are accepted ways of establishing and maintaining belonging, for others in a community 
normative practices of belonging may require disrupting or at least broadening the established ways of how one belongs. The established form of belonging that was examined in detail was the idea of being a local, a way of belonging that appears to be based on membership, though is constituted through a range of boundary-making practices. Being a local, as we have seen in the case of Cronulla in December 2005, can be the subject of sometimes intense border security work that is simultaneously local and national in character.

Finally, this paper turned to two local projects which disrupt the exclusive bounds of local membership and establish new and inclusive practices of belonging. Lismore's Living Library and the Remembering and Healing Old Wounds project are community-based and initiated projects which enable new possibilities for belonging to be expressed in the media and to be experienced by participants. They enable bridges of belonging to be built across existing boundaries, and sometimes disrupt the very boundaries themselves. They highlight the importance of relational and practice-based models and the perils of spatial metaphors when thinking about belonging and social inclusion, for there are significant parallels between the spatial metaphors that set the boundaries of 'the social' in 'social inclusion' and 'the local community' in being a local. Spatial metaphors of society, community and inclusion lend themselves to distributional policy solutions, and these are important. A relational understanding, however, points to the underlying causes of exclusion; to the everyday practices which reinforce a sense of not belonging, whether to a community or the wider society. While it is obvious that government policy approaches to social inclusion could never include projects such as the politically contentious Remembering and Healing Old Wounds, it is important that projects are encouraged which stimulate discussion of how communities and the nation are conceived and that open up the established boundaries of belonging.

It is crucial, therefore, that as part of the Government's social inclusion agenda, it continues to commit to programs which support local level responses to relational issues of social inclusion. These programs, such as the Department of Immigration and Citizenship’s Diverse Australia Program need to ensure priority is given to projects which bring diverse elements of a community together, especially dominant and marginal groups, on equal terms. The scope of such programs also requires expanding from issues arising from multicultural difference to envelop the range of relational issues already incorporated in the social inclusion agenda such as dis/ability, homelessness, Aboriginal disadvantage, together with other issues that are 
salient at the local level. Beyond government sponsorship, there will always be a need for the project which will never be funded and would suffer through constraints if it was. These projects, such as the Remembering and Healing Old Wounds project flourish in their independence and trouble-making capacity. Such projects are also part of local-level responses to inclusion that deserve our critical attention and critical support.

\section{References}

Abergel, R., Rothemund,,A., Titley, G. \& Wootsch, P. 2005, Don't judge a book by its cover! The Living Library Organiser's Guide, Council of Europe, Budapest, 2005, p9 (online). Available: http://living-library.org/downloads.html (Accessed 20 October 2008).

Ang, I. 2008, 'Passengers on train Australia', Griffith Review, no. 19, pp.230-231.

Anthias, F. 2006, 'Belongings in a globalising and unequal world: Rethinking translocations' in N.Yuval-Davis et al., (eds) The situated politics of belonging, Sage, London, p21.

Australian Broadcasting Commission 2005, The 7:30 Report [video recording] 12 December.

Australian Broadcasting Commission 2007, JTV, Episode 21, broadcast 23 February (online). Available: http://www.abc.net.au/jtv/txt/2007 /1855866.htm (Accessed 17 Sep. 2009).

Australian Government n.d. 'Social inclusion priorities' (online). Available: http://www. socialinclusion.gov.au/Priorities/Pages/default.aspx (Accessed 17 Sep. 2009).

Babacan, H. 2008, Speech at the Plenary session '300 Days: Social Inclusion and the Rudd Government', Rights, Reconciliation, Respect, Responsibility: Planning for a socially inclusive future for Australia conference, University of Technology, Sydney, 2 October 2008 (online). Abstract available: http://www.the4rsconference.org /biographies.html\#hurriyet2 (Accessed 6 April 2009).

Ball, E. 2005, 'Towards a Greek Ecocriticism: Place Awareness and Cultural Identity in Pandelis

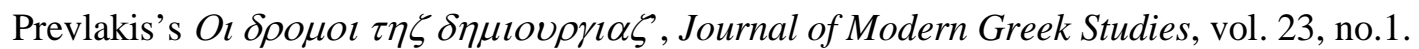

Baltruweit, S. 2009, pers. comm., 9 August.

Baltruweit, S., McIntyre, S. \& Garbutt, R. 2007, 'Lismore’s Living Library: Building communities conversation by conversation', New Community Quarterly, vol. 5, no. 4, pp.11-15.

Baxter, R. 2004, 'Six pack not so bad', The Northern Star, 17 March, p.11.

Bhambra, G. 2006, 'Culture, identity and rights: Challenging contemporary discourses of belonging' in N. Yuval-Davis et al., The situated politics of belonging, Sage, London, 2006.

Bickford, S. 1996, The dissonance of democracy: Listening, conflict, and citizenship, Cornell University Press, Ithaca.

Brookes, J. \& Appiah, K.A. 2006, 'Cosmopolitanism: How To Be a Citizen of the World', Mother Jones, February 23 (online). Available: http://www.motherjones.com/interview /2006/02/anthony_appiah.html (Accessed 23 November 2007).

Brown, J. 2009, 'Repco debate must rally community’, The Northern Star, February 9, p.11.

Cameron, A. 2006, 'Geographies of welfare and exclusion: social inclusion and exception', Progress in Human Geography, vol. 30, no. 3, p.398.

Couldry, N. 2000, Inside Culture: re-imagining the method of cultural studies, Sage, London.

Council of Europe, nd, 'The Stop the Violence movement in Denmark. An example for a peer led youth initiative’ (Online). Available: http://www.eycb.coe.int/domino /051.html (Accessed 11 September 2008). 
The Daily Telegraph, 2005, 'Calls for calm as locals plot revenge', The Daily Telegraph, 8 December, p.1.

de Certeau, M. 1984, The Practice of Everyday Life, University of California Press, Amherst.

de Vere, D. 2005, 'Let's unite to fight this shame on the beaches', The Daily Telegraph, 7 December, p.40.

Diprose, R. 2008, “ “Where’ your people from girl?”: Belonging to Race, Gender, and Place Beneath Clouds', Differences: A journal of feminist cultural studies, vol. 19, no. 3.

Edwards, J. 2000, Born and Bred: Idioms of Kinship and New Reproductive Technologies in England, Oxford University Press, Oxford, 2000.

Elder, B. 2007, Being Australian: Narratives of National Identity, Allen \& Unwin, Sydney.

Evers, C. 2006, 'Locals Only!' in Selvaraj Velayutham \& Amanda Wise (eds), Proceedings of the Everyday Multiculturalism Conference, (online). Available: http://www.crsi.mq.edu.au/news_and_events/documents/cliftonevers_000.pdf (Accessed 1 April 2009)

Fairclough,N. 2001, Language and Power, $2^{\text {nd }}$ edition, Pearson Education, Harlow.

Garbutt, R. 2005, 'Local Order', M/C Journal, vol. 7, no. 6, (online). Available: http://journal.mediaculture.org.au/0501/08-garbutt.php (Accessed 5 Sep. 2009).

Garbutt, R. 2006, 'The Locals: A Critical Survey of the Idea in Recent Australian Scholarly Writing', Australian Folklore, no 21, pp.172-192.

Garbutt, R. 2007, 'Locals Only’? Identity and place in Australian settler society', unpublished Ph.D. thesis, Southern Cross University, Lismore.

Garbutt, R. 2008, 'The living library: some theoretical approaches to a strategy for activating human rights and peace' in Rob Garbutt (ed) Activating Human Rights and Peace: Universal Responsibility Conference 2008 - Conference Proceedings, 1 - 4 July, Southern Cross University, Lismore, 2008, pp.270-278 (online). Available: http://epubs.scu.edu.au/cpsj_pubs/1// (Accessed 17 Sep. 2009).

Griffiths, T. 1996, Hunters and Collectors: The Antiquarian Imagination in Australia, Cambridge University Press, Melbourne.

Hall, S. 1996, 'On postmodernism and articulation: an interview with Stuart Hall', Hall, S., Morley, D. \& Chen, K-H. (eds) Stuart Hall: Critical Dialogues in Cultural Studies, Routledge, London.

Jackson, E. 2006, 'Riot and Revenge', Four Corners, 13 March, Australian Broadcasting Corporation (online). Transcript available: http://www.abc.net.au/4corners/content /2006/s1590953.htm (Accessed 25 August 2007).

Kijas, J. 2002, 'Moving to the Coast: Internal Migration and Place Contestation in Northern New South Wales', PhD thesis, University of Technology, Sydney.

Koler, V. \& Davidson, P. 2008, 'Social exclusion as a conceptual and grammatical metaphor: a crossgenre study of British policy making', Discourse and Society, vol. 19, no. 3, pp.307-331.

Labonte, R. 2004, 'Social inclusion/exclusion: dancing the dialectic', Health Promotion International, vol. 19, no. 1, pp.115-121.

Living Libraries Australia at http://www.livinglibraries.org.au/index.php/pages/evaluations/ (Accessed 12 Sep. 2009)

The Living Library Organisation at http://living-library.org/downloads.html (Accessed 12 Sep. 2009).

Marston, S. 2000, 'The social construction of scale', Progress in Human Geography, vol. 24, no. 2, pp.219-242.

Maxwell, R. 2008, 'Ask not for whom the road tolls...', The Northern Rivers Echo, vol. 14, no.36, 4 September (online). Available: http://www.echonews.com/index.php? page=News Article\&article $=23184 \&$ issue $=359$ (Accessed 12 April 2009). 
McCrone, D. \& Bechhofer, F. 2008, 'National identity and social inclusion', Ethnic and Racial Studies, vol. 31, no. 7, p.1246.

McIlveen, L., Lawrence, K., \& Brooker, G. 2005, 'A line in the sand', The Daily Telegraph, 10 December, p.68.

McIntyre, S. \& Garbutt, R. 2007, 'Lismore’s Living Library: Evaluation Report', p.3 (online). Available: http://www.livinglibraries.org.au/index.php/pages/evaluations/ (Accessed 12 Sep. 2009).

McKenna, Mark, 2007, 'Patriot Act', Australian Literary Review, 6 June. Available: http://www.theaustralian.news.com.au/story/0,20867,21813244-25132,00.html (Accessed June 22 2007).

Miller, L. 2003, 'Belonging to Country_A Philosophical Anthropology', Australian Studies, no. 76, pp.215-23.

Moreton-Robinson, A. \& Nicholl, F. 2007, 'We Shall Fight Them on the Beaches: Protesting Cultures of White Possession', Journal of Australian Studies, no. 89, pp.149-160.

Murphy, D. 2005, 'Thugs ruled the streets, and the mob sang Waltzing Matilda', The Sydney Morning Herald, 12 December, p.5.

Greg Myers, 2006, “'Where are you from?’ Identifying place’, Journal of Sociolinguistics, vol. 10, no. 3.

Northern Rivers Echo, 2009, 'Anzac service a promise for peace', The Northern Rivers Echo, vol.15, no. 7, 19 February (online). Available: http://www.echonews.com /index.php?page $=$ News\%20Article\&article $=25244 \&$ issue $=388$ (Accessed 12 April 2009).

Northern Star 2004, 'Co-ordinator named', The Northern Star, 18 February, p.3.

Oxford English Dictionary, 1989, $2^{\text {nd }}$ edition, Clarendon Press, Oxford, 1989.

Perera, S. 2006, 'Race Terror, Sydney, December 2005', Borderlands e-Journal, vol. 5, no. 1, §49 (online). Available: http://www.borderlandsejournal.adelaide.edu.au /vol5no1 2006/perera raceterror.htm (Accessed 25 October 2007).

Pred, A. 1990, 'In Other Wor(l)ds: Fragmented and integrated observations on gendered languages, gendered spaces and local transformation', Antipode, vol. 22, no.1.

Probyn, E. 1996, Outside Belongings, Routledge, New York.

Ramage, G. 2005, 'Respect locals or piss off!', The Daily Telegraph, 12 December, p.6.

Redmond, R. 2003, 'The perfect backdrop for local artist', The Northern Star, 11 July, p.5.

Richardson, L. \& Mumford, K. 2002, ‘Community, neighbourhood, and social infrastructure’, in Hills, J., LeGrand, J. \& Piachaud, D. (eds), Understanding Social Exclusion, Oxford University Press, Oxford, pp.202-224.

Sandercock, L. 2003, Cosmopolis II: Mongrel cities of the $21^{\text {st }}$ century, Continuum, London, 2003, p.93.

Sicakkan, H. \& Lithman, Y. 2005, Changing the basis of citizenship in the modern state: Political theory and the politics of diversity, Edwin Mellen Press, Lewiston.

Silver, H. 2007, Social Exclusion: Comparative Analysis of Europe and Middle East Youth (online), Dubai School of Government, 2007, Available: http://www.shababinclusion. org/content/document/detail/558/ (Accessed 4 Sep. 2009).

Singh, D. 2007, 'White subjectivity and racial terror: Towards an understanding of racial violence', ACRAWSA e-Journal, vol.3, no.1, p.7 (online). Available http://www.acrawsa.org.au/ejournalFiles/Volume 3, Number 1, 2007/DavidSingh.pdf (Accessed 17 September 2009)

Smith, P.M 2006, 'The Application of Critical Discourse Analysis in Environmental Dispute Resolution', Ethics, Place and Environment, vol. 9, no. 1. 
Strathern, M. 1996, 'Cutting the Network', The Journal of the Royal Anthropological Institute, vol. 2, no. 3, pp.517-535.

Sword, T, 2009, 'Peace is a many splintered thing', The Northern Rivers Echo, vol.15, no.7, 19 February (online). Available: http://www.echonews.com/index.php? page $=$ News\%20Article\&article $=26061 \&$ issue $=399$ (Accessed 12 April 2009).

Sylvain, R. 2005, 'Loyalty and treachery in the Kalahari', Meneley, A. \& Young, D. (eds), Autoethnographies: The anthropology of academic practices, Broadview Press, Peterborough.

TCN9, 2005, National Nine News, TCN9, Sydney, 11 December.

Vinson, T. 2007, Dropping Off the Edge: The distribution of disadvantage in Australia, Jesuit Social Services / Catholic Social Services Australia, Richmond.

Yuval-Davis, N., Kannabiran, K. \& Vieten, U. 2006, 'Introduction: Situating contemporary politics of belonging' in N.Yuval-Davis, K. Kannabiran \& U. Vieten (eds), The situated politics of belonging, Sage, London.

Zylinska, J. 2005, The ethics of cultural studies, Continuum, London. 